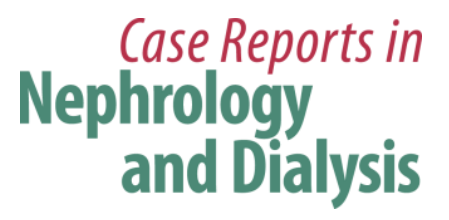

Case Rep Nephrol Dial 2018;8:147-154

DOI: 10.1159/000491630

Published online: August 10, 2018

(c) 2018 The Author(s)

Published by S. Karger AG, Basel

www.karger.com/cnd

This article is licensed under the Creative Commons Attribution-NonCommercial 4.0 International License (CC BY-NC) (http://www.karger.com/Services/OpenAccessLicense). Usage and distribution for commercial purposes requires written permission.

\title{
A Case of Chronic Calcium Oxalate Nephropathy due to Short Bowel Syndrome and Cholecystectomy
}

\author{
Seiji Hashimoto ${ }^{a}$ Rie Yamamoto ${ }^{b}$ Tomochika Maoka $^{b}$ \\ Yuichiro Fukasawa ${ }^{c}$ Takao Koike $^{d}$ Takashi Shigematsu $^{\mathrm{e}}$ \\ ${ }^{a}$ Department of Nephrology, Kinan Hospital, Tanabe, Japan; ${ }^{b}$ Department of Nephrology, \\ NTT East Japan Sapporo Hospital, Sapporo, Japan; 'Department of Pathology Diagnosis, \\ Sapporo City General Hospital, Sapporo, Japan; dDepartment of Internal Medicine II,

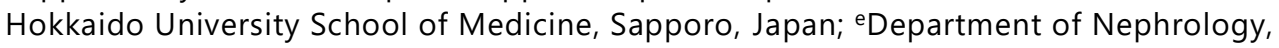 \\ Wakayama Medical University, Wakayama, Japan
}

\section{Keywords}

Oxalate $\cdot$ Renal failure $\cdot$ Ultrasound

\begin{abstract}
Background: Oxalate nephropathy is a rare disease. Especially chronic oxalate nephropathy still has many unknown aspects as compared to acute oxalate nephropathy with relatively wellknown causality. Case Presentation: The patient was a 70-year-old woman who had a history of small bowel resection 25 years before, cholecystectomy 10 years before, and renal stones (calcium oxalate stones) 7 years before. She had been suffering from chronic diarrhea and had been treated by a local physician. The patient was found to have renal dysfunction (creatinine $3.09 \mathrm{mg} / \mathrm{dL}$, eGFR $12.3 \mathrm{~mL} / \mathrm{min} / 1.73 \mathrm{~m}^{2}$, hemoglobin $7.8 \mathrm{~g} / \mathrm{dL}$ ) and was referred to our department. The patient was admitted to our hospital for further investigation. Renal ultrasound showed hepatorenal echo contrast in an opposite manner and clear contrast between the renal cortex and medullary pyramid. Renal biopsy was performed, and histological examination
\end{abstract}




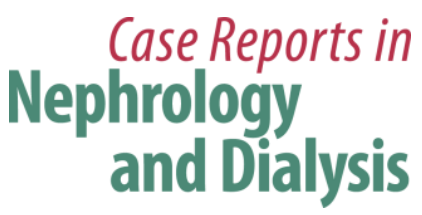

\begin{tabular}{l|l} 
Case Rep Nephrol Dial 2018;8:147-154 \\
\hline DOI: 10.1159/000491630 & $\begin{array}{l}\text { (c) 2018 The Author(s). Published by S. Karger AG, Basel } \\
\text { www.karger.com/cnd }\end{array}$
\end{tabular}

Hashimoto et al.: A Case of Chronic Calcium Oxalate Nephropathy due to Short Bowel Syndrome and Cholecystectomy

showed tubulointerstitial disorder due to deposition of calcium oxalate. Daily urinary excretion of calcium oxalate was significantly increased. The patient was encouraged to drink water and administered vitamin $\mathrm{B}_{6}$, citric acid, $\mathrm{K}$ and $\mathrm{Na}$ hydrate. Thereafter, her symptoms improved. Conclusion: Case reports of chronic oxalate neuropathy are rare in the literature, and its underlying mechanism has not been understood. Our patient had a history of small bowel resection and cholecystectomy. We considered that her short bowel syndrome had influenced the development of calcium oxalate nephropathy.

(C) 2018 The Author(s)

Published by S. Karger AG, Basel

\section{Introduction}

Renal dysfunction due to deposition of oxalate in renal tissue is a relatively rare condition, and it is termed oxalate neuropathy [1]. Oxalate nephropathy can be divided into acute and chronic forms. It is well known that acute oxalate nephropathy can be caused by accidental or suicidal ingestion of ethylene glycol [2]. Among chronic forms, hereditary primary hyperoxaluria is relatively well known, and its pathogenesis is under intense investigation [3]. Case reports of acquired chronic oxalate nephropathy, on the other hand, are rare. Chronic oxalate nephropathy may not be well recognized. This condition is reportedly attributable to chronic excessive oxalate consumption and enteric malabsorption. Chronic excessive consumption of oxalate is more likely to be involved in this condition as compared to enteric malabsorption [4]. Cases attributable to enteric malabsorption are considered to result from gastrointestinal surgery or gastrointestinal diseases, such as Crohn disease, and its pathological condition is not clearly understood [5]. Here, we report a rare case of acquired chronic oxalate nephropathy with the characteristic echo findings and discuss the condition, including pathogenesis.

\section{Case Report}

A 70-year-old woman was referred by a local physician to our hospital for detailed investigation of renal function. On admission, her height was $159 \mathrm{~cm}$, weight was $48 \mathrm{~kg}$, body temperature was $36.2^{\circ} \mathrm{C}$, pulse was $72 \mathrm{bpm}$, and blood pressure was $154 / 74 \mathrm{~mm} \mathrm{Hg}$. Her physical findings were not remarkable. Family history was not remarkable except for pancreatic cancer of her father.

Twenty-six years before, the patient had developed intestinal obstruction and undergone small bowel resection. Although the small bowel was partially resected, it was unknown how long the resected small bowel was due to lack of medical records. After the small bowel resection, the patient had often experienced diarrhea or loose stools. Ten years prior to admission, the patient had undergone cholecystectomy for gallstones. Her chronic diarrhea had been aggravated after cholecystectomy. Eight years before, the patient had undergone extracorporeal shock wave transurethral lithotripsy for renal stones. The collected stones were calcium oxalate stones. Her renal function at that time was unknown. Approximately 3 years before, the patient had experienced further aggravation of chronic diarrhea and started to receive treatment for diarrhea, hypertension, and dyslipidemia at a local clinic. Amlodipine, atorvastatin, and an antiflatulent were started. Laboratory findings at that time were blood urea nitrogen 


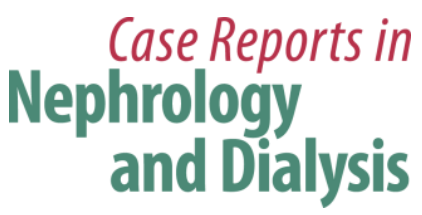

\begin{tabular}{l|l} 
Case Rep Nephrol Dial 2018;8:147-154 \\
\hline DOl: 10.1159/000491630 & $\begin{array}{l}\text { @ } 2018 \text { The Author(s). Published by S. Karger AG, Basel } \\
\text { www.karger.com/cnd }\end{array}$
\end{tabular}

Hashimoto et al.: A Case of Chronic Calcium Oxalate Nephropathy due to Short Bowel Syndrome and Cholecystectomy

(BUN) $9.1 \mathrm{mg} / \mathrm{dL}$, creatinine (Cr) $0.79 \mathrm{mg} / \mathrm{dL}$, and hemoglobin (Hb) $11.2 \mathrm{~g} / \mathrm{dL}$. Since then, the patient had experienced diarrhea several times a day and rarely had normal stools. In February of the year prior to admission, laboratory findings showed renal dysfunction (BUN 21.3 $\mathrm{mg} / \mathrm{dL}, \mathrm{Cr} 1.23 \mathrm{mg} / \mathrm{dL}$, and $\mathrm{Hb} 11.2 \mathrm{~g} / \mathrm{dL}$ ). There was no hematuria or proteinuria. In September of that year, laboratory findings showed aggravation of renal function (BUN $52.7 \mathrm{mg} / \mathrm{dL}$, Cr $3.09 \mathrm{mg} / \mathrm{dL}$, and $\mathrm{Hb} 7.8 \mathrm{~g} / \mathrm{dL}$ ). The patient was admitted to our hospital for further examination and treatment.

The test results on admission are shown in Table 1. Her renal function showed further aggravation ( $\mathrm{Cr} 3.36 \mathrm{mg} / \mathrm{dL}$ ). The levels of urinary beta-2 microglobulin and urinary NAG were elevated. Blood gas analysis showed metabolic acidosis. Daily urinary excretion of calcium oxalate measured by 24-hour urine collection was $141 \mathrm{mg} /$ day (reference value, 9.0$37.7 \mathrm{mg} /$ day).

Figure 1 shows the plain abdominal computed tomography image. There were no significant abnormalities, although there was mild dilatation of the left renal pelvis and urinary tract probably attributable to past effects of calcium oxalate stones.

Figure 2 shows the renal ultrasound image. The entire kidneys were slightly atrophic. There was hepatorenal echo contrast in an opposite manner and increased echogenicity of the renal medulla and cortex. A hypertrophic column of Bertin was present with an increased echogenicity, and the contrast between the columns and the medullary pyramid was evident.

Figure 3, Figure 4, and Figure 5 show the histological findings of renal tissue. There were no significant changes in the glomeruli, and infiltration of inflammatory cells in the tubulointerstitium was observed (Fig. 3). There were renal tubules containing a clear or crystal substance (Fig. 4), and the contents were positive for Kossa stain (Fig. 5). They were hyperechoic under a polarizing microscope.

Based on these findings, the patient was diagnosed with oxalate nephropathy. We took a careful dietary history, including the presence/absence of biased nutrition. However, she had no obvious biased nutrition. The patient was not taking other drugs or supplements. It was revealed that her daily water intake was $1 \mathrm{~L}$ or less. We considered that the reduced water intake might have been an aggravating factor and encouraged the patient to drink more water. Pyridoxine $10 \mathrm{mg}$ and potassium citrate-citrate sodium $2 \mathrm{~g}$ were started. After that, her serum Cr decreased gradually to $2.9 \mathrm{mg} / \mathrm{dL} 1$ month later, $2.8 \mathrm{mg} / \mathrm{dL} 2$ months later, and to 2.1 $\mathrm{mg} / \mathrm{dL} 1$ year later and then remained at the same level.

\section{Discussion}

The pathogenesis of hereditary oxalate nephropathy is under intense investigation, and 3 genetic types have been reported [3]. The disease is inherited in an autosomal recessive fashion and caused by abnormality of the enzyme involved in glyoxylate metabolism. The prognosis of this condition is poor because patients develop hepatic failure or renal failure due to deposition of oxalate in the organs when they reach adulthood. It is clear that our case does not fall into this category.

Regarding acquired oxalate nephropathy, it is well known that acute renal failure from acute oxalate nephropathy is caused by ingestion of large amounts of ethylene glycol (usually as a suicide attempt) [2]. A study reported that ingestion of large amounts of ascorbic acid can 


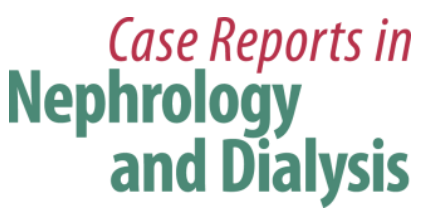

\begin{tabular}{l|l} 
Case Rep Nephrol Dial 2018;8:147-154 \\
\hline DOI: 10.1159/000491630 & $\begin{array}{l}\text { @ 2018 The Author(s). Published by S. Karger AG, Basel } \\
\text { www.karger.com/cnd }\end{array}$ \\
\hline
\end{tabular}

Hashimoto et al.: A Case of Chronic Calcium Oxalate Nephropathy due to Short Bowel Syndrome and Cholecystectomy

cause acute renal failure because ascorbic acid is metabolized to oxalate [6], while another recent study denied the hypothesis $[7,8]$.

Regarding the chronic condition, calcium oxalate is a well-known component of urinary stones, which are known to cause renal dysfunction in a huge number of cases [9]. However, chronic oxalate nephropathy due to deposition of oxalate in renal tissue is rare. It is, therefore, assumed that pathological deposition of oxalate is not observed in the general population. Previous studies reported that the condition is associated with ingestion of large amounts of foods and supplements containing oxalate, such as tea [10], spinach [11], and ascorbic acid [7]. There are also case reports of oxalate nephropathy following ingestion of large amounts of Averrhoa bilimbi juice [12] or rhubarb [13]. However, our patient did not have habitual intake of such foods.

Recently, an association between oxalate nephropathy and gastrointestinal surgery has been reported [14]. Case reports of calcium oxalate urinary stones associated with jejunoileal bypass or Roux-en-Y gastric bypass for obesity have been published. Although our patient had not undergone such a surgery, she had undergone small bowel resection for intestinal obstruction. As the patient had short bowel syndrome, it is speculated that her impaired fat absorption increased fat in the intestine, which decreased free $\mathrm{Ca}^{2+}$ due to binding of $\mathrm{Ca}^{2+}$ to the intestinal fat. This may have caused calcium oxalate to decrease and free oxalate to increase, which increased absorption of oxalate in blood, leading to deposition of oxalate in renal tissue [15].

In addition to the small bowel resection, our patient had undergone cholecystectomy after having small bowel resection. After cholecystectomy, her chronic diarrhea had been aggravated. It was assumed that resection of the gallbladder resulted in a further aggravation of enteric malabsorption of fat, thereby causing the deposition of oxalate. It is assumed that her calcium oxalate urinary stones 8 years before and oxalate nephropathy at present have the same underlying mechanism. The aggravation of renal dysfunction in recent years might be related to aggravation of chronic diarrhea with age and deterioration of the intestinal environment due to reduced water intake and other causes.

A further element of note in this case was our patient's characteristic echo findings. The increased echogenicity of the renal medulla and cortex and column of Bertin was probably due to deposition of calcium oxalate. Therefore, when an ultrasound examination shows these features, clinicians should consider the possible diagnosis of oxalate nephropathy.

In conclusion, we report a case of chronic oxalate nephropathy due to short bowel syndrome. It is possible that not only short bowel syndrome but also cholecystectomy may affect the onset of the disease.

\section{Statement of Ethics}

The authors have no ethical conflicts to disclose, and the patient provided informed consent. 


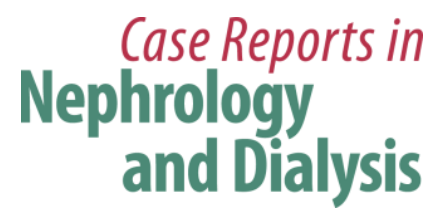

Case Rep Nephrol Dial 2018;8:147-154

DOI: $10.1159 / 000491630$

(C) 2018 The Author(s). Published by S. Karger AG, Basel www.karger.com/cnd

Hashimoto et al.: A Case of Chronic Calcium Oxalate Nephropathy due to Short Bowe Syndrome and Cholecystectomy

\section{Disclosure Statement}

The authors declare that they have no relevant financial interests.

\section{Author Contributions}

Designated authors meet all 4 criteria for authorship in the ICMJE recommendations. Individual contribution of each author is as follows. S.H. is responsible for the manuscript. R.Y. and T.M. treated the patient as an inpatient and made decisions about the patient's examinations and therapies. T.K. reviewed previous publications and wrote the whole manuscript. Y.F. is a pathologist and performed the pathological diagnosis of this case. All authors read and approved the final manuscript.

\section{References}

1 Ligon CB, Hummers LK, McMahan ZH. Oxalate nephropathy in systemic sclerosis: case series and review of the literature. Semin Arthritis Rheum. 2015 Dec;45(3):315-20.

2 Seo JW, Lee JH, Son IS, Kim YJ, Kim DY, Hwang Y et al. Acute oxalate nephropathy caused by ethylene glycol poisoning. Kidney Res Clin Pract. 2012 Dec;31(4):249-52.

3 Cochat P, Rumsby G. Primary hyperoxaluria. N Engl J Med. 2013 Aug;369(7):649-58.

4 Getting JE, Gregoire JR, Phul A, Kasten MJ. Oxalate nephropathy due to 'juicing': case report and review. Am J Med. 2013 Sep;126(9):768-72.

5 Nazzal L, Puri S, Goldfarb DS. Enteric hyperoxaluria: an important cause of end-stage kidney disease. Nephrol Dial Transplant. 2016 Mar;31(3):375-82.

6 Lawton JM, Conway LT, Crosson JT, Smith CL, Abraham PA. Acute oxalate nephropathy after massive ascorbic acid administration. Arch Intern Med. 1985 May;145(5):950-1.

7 Curhan GC, Willett WC, Speizer FE, Stampfer MJ. Intake of vitamins B6 and C and the risk of kidney stones in women. J Am Soc Nephrol. 1999 Apr;10(4):840-5.

8 Gerster H. No contribution of ascorbic acid to renal calcium oxalate stones. Ann Nutr Metab. 1997;41(5):269-82.

9 Kang HW, Seo SP, Kim WT, Kim YJ, Yun SJ, Lee SC et al. Effect of renal insufficiency on stone recurrence in patients with urolithiasis. J Korean Med Sci. 2014 Aug;29(8):1132-7.

10 Syed F, Mena-Gutierrez A, Ghaffar U. A case of iced-tea nephropathy. N Engl J Med. 2015 Apr;372(14):13778.

11 Forzán MJ, Ferguson LV, Smith TG. Calcium oxalate nephrolithiasis and tubular necrosis in recent metamorphs of Rana sylvatica (Lithobates sylvaticus) fed spinach during the premetamorphic (tadpole) stage. Vet Pathol. 2015 Mar;52(2):384-7.

12 Krishnan D, Thomas R, Balakrishnan S, Viswanathan P. Acute oxalate nephropathy due to "Averrhoa bilimbi" Juice. J Assoc Physicians India. 2016 Jan;64(1):122-3.

13 Albersmeyer M, Hilge R, Schröttle A, Weiss M, Sitter T, Vielhauer V. Acute kidney injury after ingestion of rhubarb: secondary oxalate nephropathy in a patient with type 1 diabetes. BMC Nephrol. 2012 Oct;13(1):141.

14 Agrawal V, Wilfong JB, Rich CE, Gibson PC. Reversal of Gastric Bypass Resolves Hyperoxaluria and Improves Oxalate Nephropathy Secondary to Roux-en-Y Gastric Bypass. Case Rep Nephrol Dial. 2016 Sep;6(3):114-9.

15 Emmett M, Guirl MJ, Santa Ana CA, Porter JL, Neimark S, Hofmann AF et al. Conjugated bile acid replacement therapy reduces urinary oxalate excretion in short bowel syndrome. Am J Kidney Dis. 2003 Jan;41(1):230-7. 


\section{Case Reports in Nephrology and Dialysis}

Case Rep Nephrol Dial 2018;8:147-154

DOI: $10.1159 / 000491630$

(c) 2018 The Author(s). Published by S. Karger AG, Basel www.karger.com/cnd

Hashimoto et al.: A Case of Chronic Calcium Oxalate Nephropathy due to Short Bowe Syndrome and Cholecystectomy

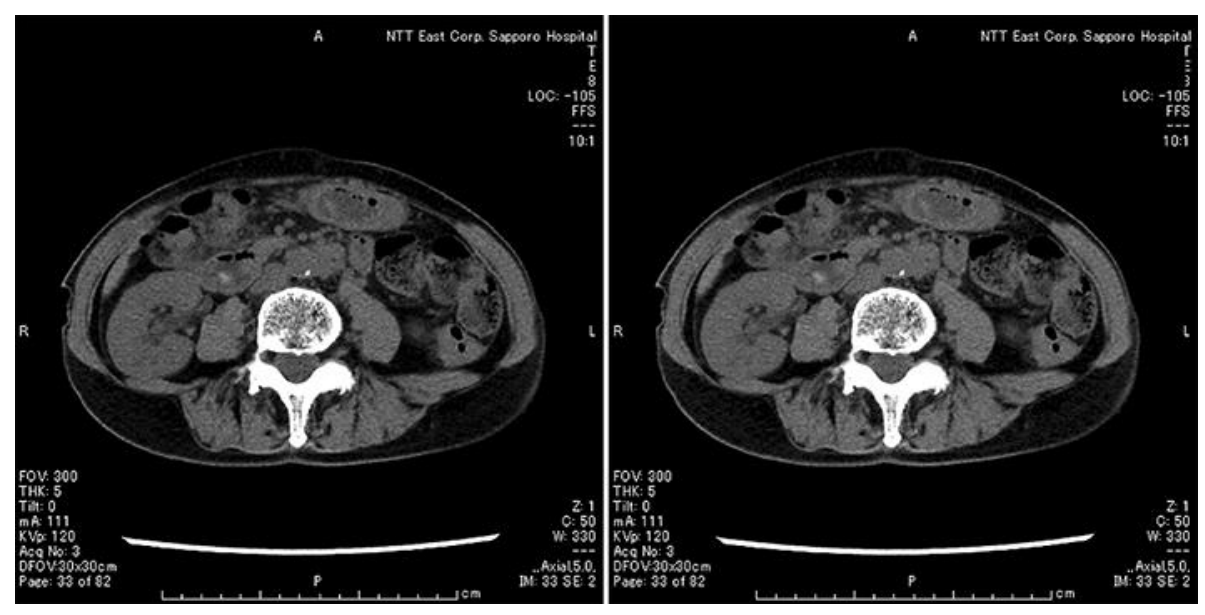

Fig. 1. Plain abdominal computed tomography image.
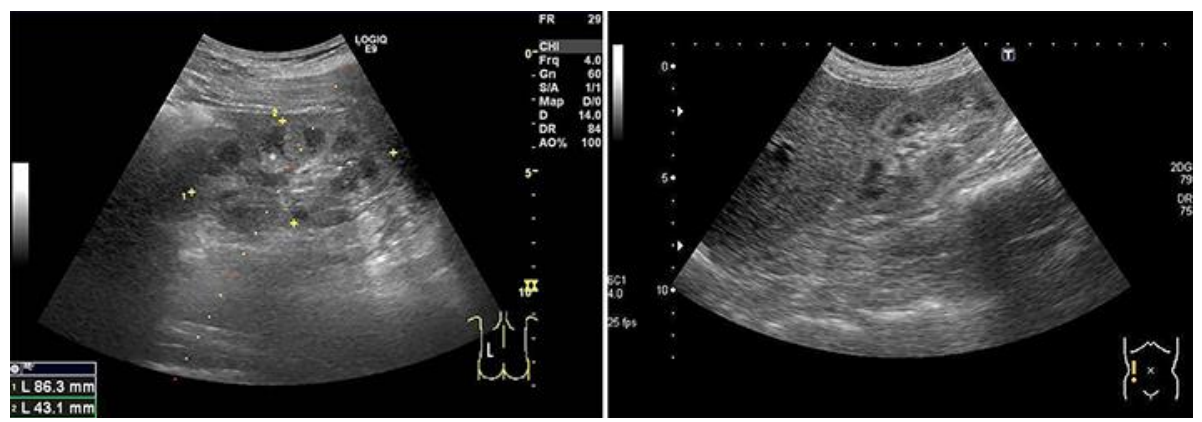

Fig. 2. Renal ultrasound image. 


\section{Case Reports in Nephrology and Dialysis}

www.karger.com/cnd

Hashimoto et al: A Case of Chronic Calcium Oxalate Nephropathy due to Short Bowe Syndrome and Cholecystectomy

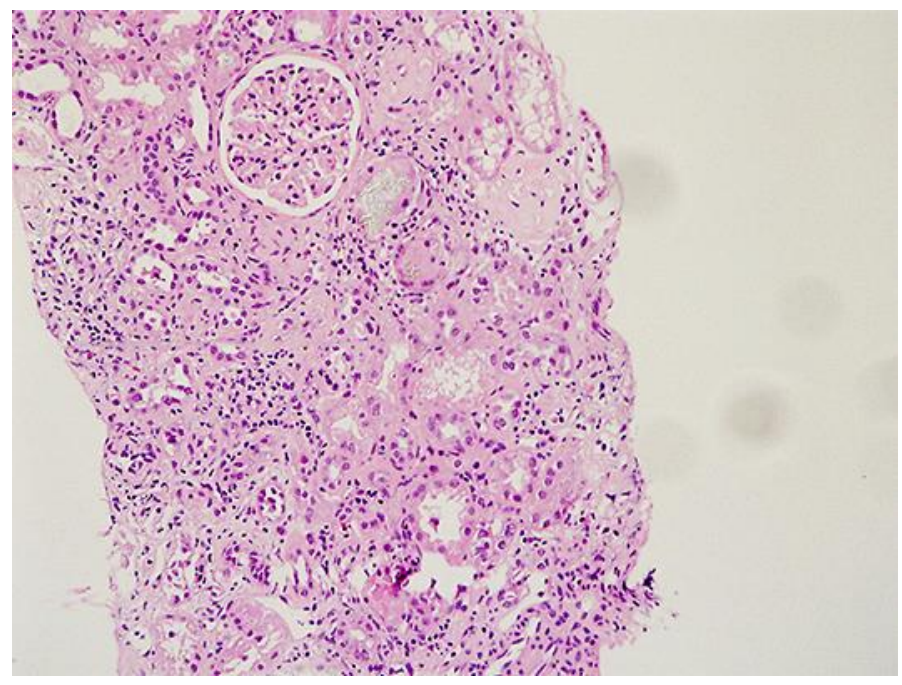

Fig. 3. Histological findings of renal tissue. HE, $\times 40$.

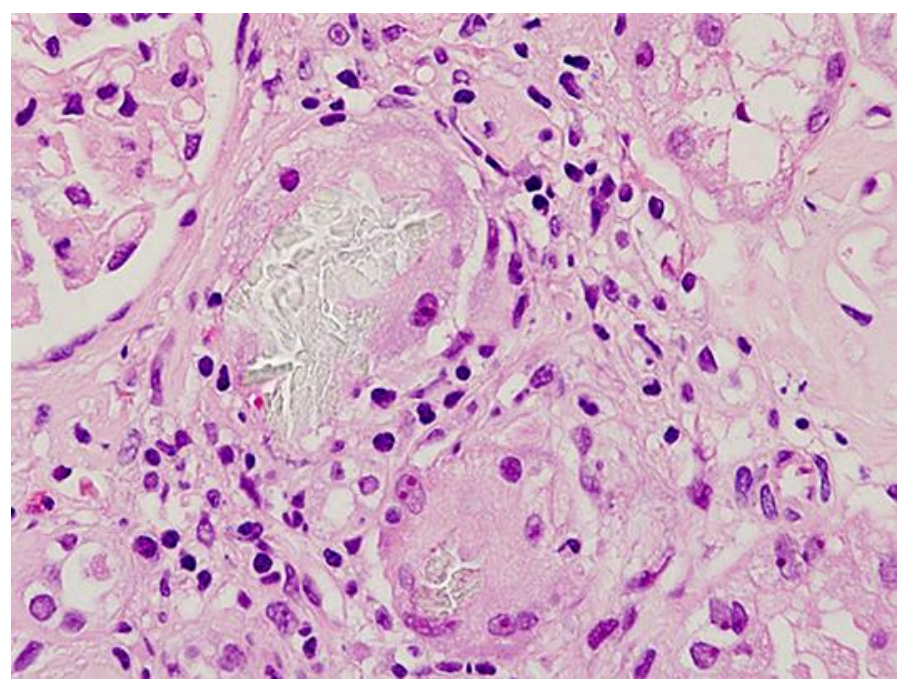

Fig. 4. Histological findings of renal tissue. HE, $\times 400$. 


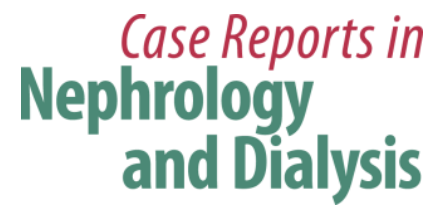

(C) 2018 The Author(s). Published by S. Karger AG, Basel www.karger.com/cnd

Hashimoto et al.: A Case of Chronic Calcium Oxalate Nephropathy due to Short Bowe Syndrome and Cholecystectomy

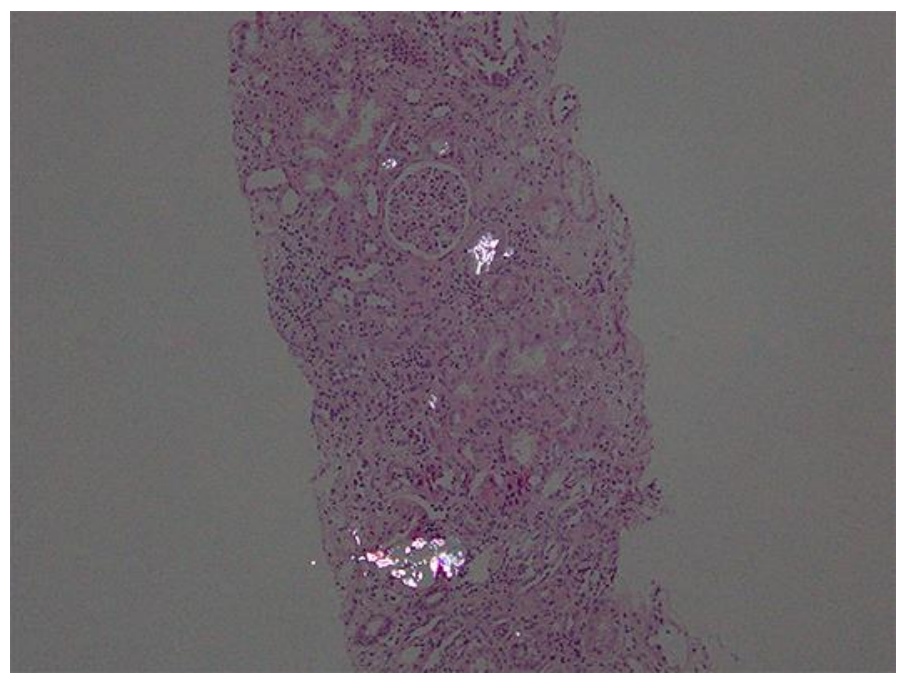

Fig. 5. Histological findings of renal tissue. Kossa stain image taken under polarizing microscope.

Table 1. Test results on admission

\begin{tabular}{|c|c|c|c|c|c|}
\hline \multicolumn{3}{|l|}{ Blood chemistry } & \multicolumn{3}{|l|}{ Blood gas analysis } \\
\hline Total Protein $(6.5 \sim 8.0)$ & 6.5 & $\mathrm{~g} / \mathrm{dL}$ & $\mathrm{pH}(7.35 \sim 7.45)$ & 7.306 & \\
\hline Albumin (3.8 5.3) & 3.9 & $\mathrm{~g} / \mathrm{dL}$ & $\mathrm{pCO}_{2}(35 \sim 45)$ & 29.9 & mm Hg \\
\hline AST (10 34) & 17 & IU/L & $\mathrm{HCO}_{3}(22 \sim 26)$ & 14.6 & $\mathrm{mEq} / \mathrm{L}$ \\
\hline ALT (13 30) & 14 & IU/L & Base excess $(-2 \sim+2)$ & -10.6 & $\mathrm{mEq} / \mathrm{L}$ \\
\hline LDH (124 222) & 206 & IU/L & Others & & \\
\hline$\gamma$-GTP $(5 \sim 24)$ & 11 & IU/L & PR3-ANCA & $<1.0$ & $\mathrm{U} / \mathrm{mL}$ \\
\hline BUN (8 20) & 48 & $\mathrm{mg} / \mathrm{dL}$ & MPO-ANCA & $<1.0$ & $\mathrm{U} / \mathrm{mL}$ \\
\hline Cre (0.4 1.0) & 3.36 & $\mathrm{mg} / \mathrm{dL}$ & intact-PTH (15 65) & 162 & $\mathrm{pg} / \mathrm{mL}$ \\
\hline Uric acid (2.5 6.0) & 5.6 & $\mathrm{mg} / \mathrm{dL}$ & erythropoietin $(4 \sim 23)$ & 6.9 & $\mathrm{mIU} / \mathrm{mL}$ \\
\hline Sodium (135 148) & 140 & $\mathrm{mEq} / \mathrm{L}$ & Urinalysis & & \\
\hline Potassium $(3.6 \sim 5.0)$ & 3.8 & $\mathrm{mEq} / \mathrm{L}$ & Urine protein & 2.2 & $\mathrm{~g} / \mathrm{g} \times \mathrm{Cr}$ \\
\hline Calcium (8.4 10.2) & 8.2 & $\mathrm{mg} / \mathrm{dL}$ & Occult blood & & $(-)$ \\
\hline Complete blood count & & & Glucose & & $(3+)$ \\
\hline White blood cells $(3,000 \sim 8,000)$ & 4400 & $/ \mu \mathrm{L}$ & $\beta 2 \mathrm{MG} / \mathrm{Cr}(1 \sim 300)$ & 215,260 & $\mu \mathrm{g} / \mathrm{g} \times \mathrm{Cr}$ \\
\hline $\mathrm{Hb}(11.5 \sim 14.7)$ & 12.4 & $\mathrm{~g} / \mathrm{dL}$ & $\mathrm{NAG} / \mathrm{Cr}(1.6 \sim 5.8)$ & 21.9 & $\mathrm{U} / \mathrm{g} \times \mathrm{Cr}$ \\
\hline Blood platelets $(1,620,000 \sim 3,290,000)$ & 140,000 & $/ \mu \mathrm{L}$ & Transferrin $(0 \sim 100)$ & 4,465 & $\mu \mathrm{g} / \mathrm{g} \times \mathrm{Cr}$ \\
\hline
\end{tabular}

Values in parentheses show the reference values. AST, aspartate aminotransferase; ALT, alanine aminotransferase; $\mathrm{LDH}$, lactate dehydrogenase; $\gamma$-GTP, gamma-glutamyltransferase; BUN, blood urea nitrogen; $\mathrm{Cr}$, creatinine; $\mathrm{Hb}$, hemoglobin; intact-PTH; intact-parathormone; $\beta 2 \mathrm{MG} / \mathrm{Cr}$, beta 2-microglobulin/Cr ratio; NAG/Cr, N-acetyl- $\beta$-Dglucosaminidase/Cr ratio. 